\title{
MANAJEMEN PENDIDIKAN MULTIKULTUR DAN AKTUALISASI ISLAM MODERAT DALAM MEMPERKOKOH NASIONALISME DI INDONESIA
}

\author{
Subandi ${ }^{1}$ \\ ${ }^{1}$ Universitas Islam Negeri Radin Intan, Lampung \\ *CORRESPONDENCE: \ subandi@ radenintan.ic.id
}

\section{Abstract}

The purpose of this study is to describe the management of multicultural education in instilling the value of Indonesian culture through learning in educational institutions to cultivate and instill a variety of cultures, religions and Indonesia, this is an engineering or developmental ideas in learning from the age of elementary school to university, so as to be able to provide the basis of national values (nationalism), tolerance and not thinking and acting radically. This research is a field research with a descriptive qualitative approach with a tool to collect observation data, interviews from several key informants and analyze them with inductive thinking. The development of multicultural education in fostering a spirit of nationalism, and radicalism in radicalism, is carried out through: 1. Integrating moderate Islam by planting the attitudes of tawassuth, tassamuh, and tawazun, 2. Introducing the environment around as plural learning (contectual learning), 3. Instill the attitude of anti-violence truth rahmatan lil alamin These three things as engineering application of material development, are thoroughly integrated in the learning process in the classroom and outside the classroom. Conclusion, Education is carried out programmatically while: 1). Transformation of knowledge through the understanding of contemporary Islam, 2). Adopt good culture (repertoire), 3). Acting in the educational environment with the attitudes of tawassuth, tassamuh and tawazun, amar ma'ruf nahimunkar anti violence 4) Performed in the form of behavior and developing tepo seliro tolerant concepts on all learning processes and 5) Character of nationalism in life (Khoirunas Anfauhum Linnas). The impact that arises in a timely manner recognizes moderate Islam, fosters the development of nationalism fostering a sense of love for the land as a manifestation of the preservation of Islam rahmatan lil alamin and strengthening the unity of the Indonesian nation.

\begin{abstract}
Abstrak
Tujuan penelitian ini untuk mendiskripsikan manajemen pendidikan multikultur dalam menanamkan nilai budaya Indonesia melalui pembelajaran di lembaga pendidikan untuk menumbuhkan dan menanamkan tentang ragam budaya, ragam agama dan ke-Indosnesia-an, hal tersebut merupakan rekayasa atau ide-ide pengembangan dalam pembelajaran sejak usia sekolah dasar sampai perguruan tinggi, sehingga mampu memberikan dasar-dasar nilai kebangsaan (nasionalisme), toleransi dan tidak berfikir dan bertidak radikal. Penelitian ini adalah peneitian lapangan dengan pendekatan diskriptif kualitatatif dengan alat pengumpul data observasi, wawancara dari beberapa informan kunci dan dianalisa dengan pemikiran induktif. Pengembangan pendidikan multikultur dalam menumbuhkan semangat nasionalisme, dan menderadikalisai paham radikal, dilakukan melalui yaitu: 1. Mengintegrasikan Islam moderat dengan penanaman sikap tawassut, tasāmuh, dan tawāzun, 2. Mengenalkan lingkungan sekitar sebagai kemajemukan (contextual learning), 3. Menanamkan sikap kebenaran anti kekerasan rahmatan lil ālamīn. Ketiga
\end{abstract}

Article Info

Article History

Received : 22-12-2018,

Revised : 27-12-2018,

Accepted : 28-12-2018

Keywords:

Management;

Multiculture;

Moderate Islam;

Nationalism;

\section{Histori Artikel}

Diterima: 22-12-2018

Direvisi: 27-12-2018

Disetujui: 28-12-2018 
hal tersebut sebagai rekayasa penerapan pengembangan materi, terintegrasi secara menyeluruh dalam proses pembelajaran dalam kelas maupun di luar kelas. Pendidikan dilaksanakan secara terprogram dengan cara: 1 . Mentranformasi ilmu melalaui pemahaman Islam moderat, 2). Mengadopsi budaya yang baik (hasanah), 3. Melakukan aksi nyata di lingkungan pendidikan dengan sikap tawassut, tasāmuh, dan tawāzun, amar ma'ruf nahimunkar anti kekerasan 4) Dilakukan dalam bentuk prilaku dan mengembangkan kosep toleran tepo seliro pada semua lini proses pembelajaran dan 5. Karakter nasionalisme dalam kehidupan (Khoirunas Anfauhum Linnas ). Dampak yang timbul secara perlahan mengenal Islam moderat, menumbuhkembangkan nasionalisme kebangsaan memupuk rasa cinta tanah air sebagai wujud pelestarian Islam rahmatan lil alamin dalam memperkokoh persatuan bangsa Indonesia.

Kata Kunci:

Manajemen;

Multikultur;

Islam Moderat;

Nasionalisme;

\section{A. Pendahuluan}

Bangsa Indonesia adalah bangsa yang tingkat kemajemukanya sangat besar atau multikultur terbesar di dunia, dan multi agama serta kepercayaan. Kesemuanya ini diberikan perlindungan dan kemerdekaan oleh negara sesuai termaktup dalam Falsafah Negara Pancasila dan UUD 1945 pasal 29 ayat 1, 2, kebebasan ini diatur oleh aturan perundang-undangan sehingga pemeluk agama mampu meyakini dan menjalankan syariat sesuai dengan agama yang dianutnya masing-masing. Pada posisi tersebut bangsa Indonesia dihadapkan banyak persoalan yang tidak mudah untuk mengatasinya, pada era abad 21 dan kemajuan teknologi yang sangat pesat ditandai dengan, mobilitas manusia yang tinggi, integrasi budaya dan penetrasi budaya serta destinasi wisata dunia, maka tidak mudah bagi bangsa Indonesia untuk tetap menjaga kebhinekaan dan nasionalisme dari ancaman radikalisme dan teroris yang secara sengaja mengancam keutuhan bangsa Indonesia.

Dalam sepuluh tahun terakhir kasus kekerasan dan kerusuhan meningkat tajam, baik dari sisi kuantitas jumlah kasus maupun kualitas intensitas kasus yang terjadi kasus kekerasan terjadi dalam berbagai dimensi, ada yang bermatras politik, ekonomi, agama dan lain-lain. Merujuk laporan penelitian United Nations Support Facility for Indonesian Recovery (UNSFIR) tahun 2002, kekerasan sosial di Indonesia selama 1990-2001 telah menyebabkan setidaknya 6.208 jiwa kehilangan nyawa. Di antara empat kategori kekerasan sosial, kekerasan komunal adalah jenis kekerasan sosial yang terparah jika diukur dengan jumlah korban tewas. Kekerasan komunal tercatat sekitar 77\% (atau 4.771 jiwa) dari total korban tewas akibat kekerasan sosial, diikuti oleh kekerasan separatis dengan 22\% korban tewas (atau 1.370 jiwa).

Indonesia saat ini sedang dihadapkan pada krisis multidimensial. Krisis multidimensial ini sebetulnya mengakar pada menurunnya nasionalisme timbulnya radikalisme dan tindakan teroris teror bom terjadi di tiga gereja di Sidoharjo Jawa timur dan beberapa Polres di Jawa dan Sumatera serta insiden penyanderaan diserta pembunuhan di Mako Brimob Jakarta [1], kasus ini menunjukkan menurunya kualitas moral bangsa Indonesia. Hal ini dicirikan oleh membudayanya praktik Korupsi, Kolosi, dan Nepotisme (KKN), konflik antar etnis, agama, politisi, tawuran remaja, tawuran antar warga, meningkatnya kriminalitas, menurunnya etos kerja, hilangnya budaya malu, dan individualis. Persepsi internasional tentang Indonesia dalam hal kejujuran yang diukur dari tingkat transparansi penyelenggara negara, good corporate governance, sistem peradilan, dan penghormatan terhadap hak properti intelektual rendah (Transparansi Internasional, 2002 dan 2006) [2]. Rendahnya kredibilitas Indonesia di mata dunia internasional adalah cerminan dari perilaku individu-individu yang tidak berkarakter, yang membuat Indonesia terpuruk secara sosial, 
ekonomi, dan budaya. Padahal, sebelumnya Indonesia dikenal di kancah internasional sebagai bangsa yang memiliki nilai-nilai budaya yang adiluhung dengan sifat ramah tamah. Hal ini mengindikasikan bahwa telah terjadi suatu kegagalan dalam pewarisan nilai-nilai adiluhung (nilainilai karakter) dan nasionalisme. Bangsa Indonesia pada saat ini dihadapkan dengan masa globalisasi industri milenial 4.0 yang menjadi tantangan ke depan, bila tidak tanggap maka distropsi dari semua lini akan muncul termasuk munculnya paham Islam radikal dan dirilis oleh Badan Intelejen Negara Republik Indonesia tanggal 20 Nopember 2018. Survei menunjukkan dari 15 provinsi dan kota besar di Indonesia menunjukan 39\% mahasiswa di kalangan kampus ternama sudah teracuni paham radikal dan Islam radikal[3], hal tersebut menunjukkan kelalaian masyarakat khususnya civitas akademika dari perguruan tinggi di Indonesia, atau justru ketidakpiawaian para tokoh-tokoh bagsa dan pemuka agama terhadap aktualisasi bentuk ajaran Islam yang lebih moderat. Karena menurut pandangan penulis bahwa seluruh pengelola pendidikan dan lembaga pendidikan keagamaan Islam atau pengelolaan pendidikan umum mestinya memasukkan pembelajaran agama Islam yang mampu menanamkan toleransi, nuansa kemanusiaan dan kebangsaan dengan selalu menegakkan kebenaran dan keadilan berdasarkan agama yang diyakini tanpa mengunakan kekarasan.

Sependapat dengan pemikiran Hobsbawm[4], bahwa sudah sepatutnya seluruh komponen bangsa ini merefleksi dan kemudian melakukan rediscovery terhadap nilai-nilai luhur budaya bangsa atau revitalisasi atau semacam invented tradition melalui gerakan nasional yang melibatkan seluruh komponen sebagai konsensus yang lahir dari kesadaran nasional. Adapun upaya dan strategi yang tepat digunakan untuk menghadapinya adalah dengan cara menguji kembali premis-premis dan nilai budaya lama melalui bentuk-bentuk pendidikan [5].

Mengapa harus pendidikan, sebab pendidikan merupakan rangkaian tidak terpisahkan dari siklus kehidupan yang menjadi elan vital manusia. Berbagai corak dan ragam pendidikan dipandang memiliki orientasi dapat memberikan bekal yang cukup komprehensif kepada manusia untuk mencapai taraf kebahagiaan dunia dan akhirat. Di sanalah akan terlihat, sesederhana apapun peradaban suatu masyarakat bahkan bagi suku yang dianggap paling "primitif" sekalipun pasti di dalamnya telah terdapat dan berlangsung siklus pendidikan baik pendidikan dalam keluarga itu sndiri atau pendidikan yang terjadi secara langsung yang ada pada masyarakat. Pendidikan yang diciptakan oleh masyarakat untuk membantu keluarga, dan msyarakat dalam tugas menyiapkan generasi anak-anak yang belum siap dalam kehidupan sosial, dengan tujuan membantu mengembangkan dalam diri anak suatu kondisi fisik, intelektual, dan moral yang dituntut oleh masyarakat secara keseluruhan.

Anggapan tersebut masih kental dalam pemikiran masyarakat bahwa melalui pendidikanlah, anak mampu mengenal dan mengalami proses perubahan baik ilmu pengetahuan, prilaku moral dan etika serta transformasi kemajuan ilmu dan teknologi, pada hakekatnya proses pendidikan adalah proses perubahan sosial. Selanjutnya mengapa harus pendidikan dasar, pemiliran penulis menyatakan bahwa pendidikan dasar merupakan pendidikan awal bagi anak mengenal sekolah, melalui mengenal lingkungan sekitar yang terdiri dari lingkungan budaya, bahasa, suku, agama dan ras, apabila ini diberikan kurikulum atau diajarkan pendidikan awal tertang multikultur maka akan berdapak pada pengetahuan, inisiatif dan tindakan yang baik pada diri anak untuk mampu bersosialisai dengan lingkungan, secara langsung dalam pergaulan maupun secara pengetahuan dalam proses pembelajaran. Asumsi sependapat dengan James Bank 1993, bahwa pendidikan multikultur itu bisa dilaksanakan melalui pendidikan, dengan cara: direnrencanakan dalam 
kurikulum pembelajaran terintegrasi, dalam hungungan sosial, dan menjadikan kolaborasi antar individu, serta adanya toleransi. Merujuk pada pemikiran James Bank bahwa pendidikan ajaran Islam dengan paham tawassut, tasāmuh, tawazun, i'tidal, dan amar ma'ruf nahi munkar mampu menjadi ide-ide baru dan rekayasa melalui kurikulum pembelajaran, sehingga secara perlahan tapi pasti mampu untuk mengikis paham Islam radikal melalui proses pembelajaran di lingkungan lembaga pendidikan di Indonesia.

Kajian tentang pendidikan multikultural sudah banyak dilakukan oleh peneliti lain. Akan tetapi kajian tentang hubungan antara manajemen pendidikan multikultural dengan upaya membangun pendidikan Islam moderat dan sikap nasionalisme pada murid belum dikaji oleh peneliti lain. Misalnya saja penelitian yang dilakukan oleh Muhammad Sain Hanafy yang hanya mengkaji konsep pendidikan multikultural dan kaitannya dengan nilai kebangsaan.[6] Kajiannya belum sampai pada bentuk konkrit penerapan multikultural dalam ranah menanam nilai kebangsaan. Untuk itu penelitian ini menggali apa saja bentuk konkrit dari manajemen pendidikan multikultural dengan aktualisasi konsep Islam moderat dalam meningkatkan dan menguatkan nasionalisme dalam diri siswa.

\section{B. Metode Penelitian}

Penelitian ini merupakan field research (penelitian lapangan), di mana data yang diangkat adalah data dari realitas yang ada atau terjadi di lapangan untuk memperjelas kesesuaian teori. Pendekatan kualitatif suatu prosedur penelitian yang menghasilkan data deskriptif. Pendekatan ini diarahkan pada latar dan individu secara holistik (utuh). Pendekatan kualitatif memiliki karakteristik alami (natural setting). Oleh karena itu dalam penelitian kualitatif instrumennya adalah orang atau human unstrument. Untuk dapat menjadi instrumen, maka peneliti harus memiliki bekal teori dan wawasan yang luas, sehingga mampu bertanya, menganalisis, memotret, dan mengkonstruksi obyek yang diteliti menjadi lebihjelas dan bermakna.

Data yang sebenarnya terjadi sebagaimana adanya, bukan data yang sekedar terlihat, terucap, tetapi data yang mengandung makna di balik yang terlihat dan terucap tersebut[6]. Dalam penelitian ini peneliti bertindak sebagai instrumen sekaligus pengumpul data. Instrumen selain manusia dapat pula digunakan, akan tetapi fungsinya terbatas sebagai pendukung tugas peneliti instrumen. Oleh karena itu kehadiran peneliti di lapangan untuk penelitian kualitatif mutlak dilakukan atau diperlukan dalam menguraikan data nantinya.

Fokus penelitian ini yaitu manajemen mutu pada lingkungan Perguruan Tinggi Islam Nadlatul Ulama. Manajemen mutu yang menjadi fokus penelitian dapat dilihat dari prosesnya, unsur yang harus ada di dalamnya. Menurut Elton Lewis, unsur yang dikenai dapat menyangkut pembelajaran maupun pelakunya yaitu dosen yang merupakan unsur pokok [7]. Rancangan multi situs dalam pelaksanaanya menempuh langkah: (1). Meneliti secara simultan lokasi penelitian di tiga Perguruan tinggi Islam; (2). Dilakukan deskripsi hasil data yang terkumpul dari setiap situs untuk memperoleh kesimpulan utuh model manajemen mutu Perguruan Tinggi Islam Nahdlatul Ulama; dan (3). Berdasarkan kesimpulan utuh model manajemen mutu dari masing masing Perguruan tinggi Islam selanjutnya dilakukan análisis untuk menemukan manajemen mutu melalui induksi.

Data dalam penelitian ini dikumpulkan dengan tiga teknik yaitu: (1). Interview (wawancara). Interview atau tehnik wawancara dilaksanakan dengan maksud untuk mengkonstruksikan mengenai orang, kejadian, kegiatan, organisasi, perasaan motivasi, tuntutan, kepedulian dan kebutuhan lainlain [8]. Metode wawancara mendalam dilaksanakan untuk mengungkap pandangan ketiga 
perguruan tinggi NU tersebut mengenai proses pengembangan manajemen mutunya. (2). Observasi. Menurut Seltiz dimaknai sebagai proses pemilihan, pengubahan, pencatatan, dan pengkodean serangkaian perilaku dan suasana yang berkenaan dengan organisme sesuai dengan tujuan-tujuan empiris [9]. Observasi dalam penelitian ini didasarkan atas pengalaman secara langsung yang didukung dengan pengumpulan dan pencatatan data secara sistematis terhadap obyek yang diteliti[9]. Spradley membagi observasi ke dalam beberapa tahap, diantaranya adalah tahap observasi deskriptif (descriptive observation) yang menggambarkan situasi kegiatan dan aktivitas yang terjadi di lapangan, kemudian disempitkan dengan pemilihan data. (3). Dokumentasi [10]. Hal ini disebabkan data yang diperoleh lewat dokumentasi terdiri dari berbagai sumber tertulis seperti: surat, buku-buku pedoman, laporan resmi, catatan harian, catatan rapat terkait dengan pelaksanaan manajemen mutunya. Analisis data penelitian kualitatif dilakukan sejak awal kegiatan penelitian hingga akhir dengan harapan adanya konsistensi dalam analisis data. Analisis data yang digunakan dalam penelitian ini menggunakan analisis deskriptif dengan Model Analisis Interaktif dari Miles dan Huberman yang terdiri dari proses reduksi data, display data, dan verifikasi data[11]

Sementara itu pemeriksaan data dalam penelitian ini menggunakan teknik triangulasi dengan memanfaatkan sesuatu yang lain di luar data itu untuk keperluan pengecekan atau sebagai pembanding terhadap data itu. Teknik triangulasi yang paling banyak digunakan adalah melalui sumber lainnya [8]. Triangulasi dengan sumber berarti membandingkan dan mengecek balik derajat kepercayaan suatu informasi yang diperoleh melalui waktu dan alat yang berbeda dalam penelitian kualitatif [8].

\section{Pembahasan atau Analisis}

Implementasi manajemen multikultur melalui aktualisasi Islam moderat dilakukan dengan pemahaman secara bersama, kegiatan yang terrencana dalam proses pendidikan, mengamalkan Islam yang toleran dan anti kekerasan, dilakukan secara terus menerus dan konsisten serta menanamkan kebiasaan sehinga mampu membentuk budaya toleransi dan modernis tanpa kekerasan.

\section{Pemahaman radikal dan Moderat dalam beragama Islam.}

Dengan melihat fakta di lapangan ditemukan adanya dua kategori paham dalam Agama Islam, yatu: (a) Pemahaman Radikal dalam Islam. Islam Radikal adalah respon umat beragama yang dimanifestasikan dalam bentuk tindakan atau pemikiran yang ekspresif, bahkan adakalanya ditunjukkan dalam bentuk tindakan pemaksaan melalui kekerasan. Sartono Kartodirjo [12] memandang radikalisme agama sebagai gerakan keagamaan yang berusaha merombak secara total suatu tatanan politis atau tatanan sosial yang ada dengan menggunakan kekerasan. Sebuah konsepsi ekspresif yang mirip dengan konotasi revolusi. Anthony Reid mendeskripsikan revolusi sebagai restrukturisasi fundamental dari suatu sistem politik dengan kekerasan dalam waktu yang relatif singkat. Dari kedua istilah ini ada kesamaan tujuan yang sama yang ingin dicapai yaitu perubahan keadaan secara total

Radikalisme agama mulai menjadi isu utama ketika bom mengguncang ketenangan manusia. Kasus bom Bali, bom natal, World Trade Center (WTC) 11 September, KFC (Kentucky Fried Chicken) dan banyaknya kekerasan dan kerusakan tempat maksiat yang dilakukan oleh laskar-laskar dan ormas-ormas Islam Radikal, semisal Ikhwanul Muslimin Indonesia, Front Pembela Islam, Majlis Mujahidin Indonesia, Laskar Jihad Ahlussunah Wal Jamaah, Hisbullah, Jundullah dan ormas sejenis yang memiliki karakteristik serupa menyuarakan suara lantang berjihad 
melawan kedholiman. [15] Persoalan radikalisme keagamaan mencakup persoalan yang cukup komplek karena hal tersebut mencakup dimensi kehidupan seperti keyakinan, interpretasi, ajaran, hubungan personal dan kemasyarakatan. Hal tersebut terkait dengan tingkat pendidikan umat, lingkungan sosial, tradisi budaya, kemauan dan pemahaman terhadap setiap perubahan. Dengan kata lain persoalan radikalisme keagamaan akan berdimensi vertikal dan horisontal. [15] Berikut ini beberapa perspektif yang dianggap memiliki keterkaitan kuat yang melatari bangkitnya Islam Radikal. (b) Problem Mitologi Agama. Sulhan[16] melihat ada hubungan erat antara mitologi dan isu radikalisme agama. Cara pandang pemikiran mitologi cenderung anti sejarah dan anti peradaban modern. Realitas yang ada dipandang semu, maya, dan tidak sempurna. Keberagamaan yang berciri mitologi bisa melahirkan sikap radikal yang muncul dalam dua bentuk paradoksal. Pertama, Radikalisme eskapis, berusaha melepaskan kehidupan duniawi, hidup bertapa, membebaskan diri dari kenikmatan duniawi yang dianggap racun dan bersifat maya. Kedua, Radikalisme teologisideologis, membangun komunitas eksklusif, sebagai wadah dari identitas kelompok vis a vis dunia sekitarnya yang dianggap dekaden, mirip dunia iblis yang harus dibasmi. Kelompok kedua ini meyakini dirinya paling benar, paling dekat dengan Tuhan. Berperang melawan kafir adalah kebajikan sedang kematian adalah take off menuju rumah primordial Tuhan. Bagi mereka kehidupan adalah jalan menuju Tuhan, sedang kematian adalah gerbang kehidupan abadi. Sikap ideologis-teologis seperti inilah yang dapat melahirkan bencana sosial politis yang akan menimbulkan fitnah umat beragama. (c) Problem Kebangsaan dan Isu Modernitas Dalam "Radikalisme Agama dan Problem Kebangsaan", MH. Nurul Huda menulis bahwa secara historis radikalisme agama itu terkait dengan gelombang modernitas yang membanjiri negara muslim pada awal abad ke 20. Pengaruh modernitas bukan hanya pada dimensi kultural tetapi juga pada stuktural institusional seperti sains, teknologi, pendidikan, militer serta instrumen modern lainnya. Aspek lain yang juga hadir dalam konteks ini adalah pandangan mengenai kesadaran kebangsaan yang melahirkan konstruksi negara bangsa modern[17]. Reaksi muncul akibat ketidak mampuan kultur masyarakat merespon nilai-nilai dan norma baru yang diusung gelombang modernitas [17]. Kesadaran nasioanalisme yang hadir bersama modernisme di Eropa Barat tumbuh dan berkembang dari perlawanan terhadap kekuasaan yang absolut. Sementara gelombang nasionalisme di Asia, Afrika dan negara-negara muslim di Semenanjung Arab, Timur Tengah, lahir dari perlawanan terhadap kolonialisasi Eropa. Situasi ini membawa dampak traumatis, sehingga hadirnya ideologi Nasionalisme di negara muslim mengalami ketegangan yang panjang bahkan perlawanan dari unsur pembentuknya. Di samping realitas masyarakat yang plural, dipertentangkannya konsepsi negara sekuler modern dengan tatanan berdasar agama telah mempertajam ketegangan dan benturan ideologis politik yang menghambat kesadaran kebangsaan. Radikalisme di tanah air mencerminkan dari ketidakmampuan kelompok Islam menegosiasikan dogma dan doktrin keagamaan dengan realitas sosial dan kebutuhan masyarakat, tentang pentingnya wawasan kebangsaan sebagai entitas yang menjamin pluralisme. Antagonisme politik dan ideologi terlihat dalam perdebatan antara Islam dan negara ini sejak masa pergerakan kebangsaan ketika elit politik terlibat dalam perdebatan tentang kedudukan Islam di Indonesia merdeka. Kendati ada upaya mencari jalan keluar dari ketegangan ini dari era 70-an tetapi kecenderungan legalistik, formalistik dan simbolik masih berkembang pada aktifis Islam saat ini [18]. Dari beberapa perspektif di atas menyebabkan problem psikologis, politis, dan sosial yang memungkinkan suburnya gerakan radikalis Islam.

Karakteristik Islam Radikal dapat dilihat dari terminologi radikalisme yang secara esensial biasanya dikaitkan dengan pertentangan yang tajam antara nilai-nilai yang diperjuangkan oleh 
agama tertentu dengan tatanan nilai yang berlaku atau dipandang mapan saat itu. Adanya pertentangan yang tajam menyebabkan Islam Radikal selalu dikonotasikan dengan kekerasan secara fisik. Padahal radikalisme bisa saja pertentangan yang bersifat ideologis, perilaku atau tujuan-tujuan tertentu yang diperjuangkan. Hanya saja, perjuangan yang bersifat radikal umumnya bertumpu pada sebuah perubahan, sehingga berakibat pada terjadinya benturan-benturan. Ciri utama gerakan radikal biasnya aktifitasnya bersifat agresif, siap juang, bertempur, berkelahi atau berperang, terutama untuk memperlihatkan pengabdian mereka secara total terhadap suatu cita-cita. Definisi tersebut barangkali tidak lepas dari cita-cita yang diperjuangkan, misalnya bersifat radikal (dalam arti melihat persoalan sampai pada akarnya), fundamentalis (dalam arti kembali ke dasar-dasar dari suatu ajaran), dan ekstrim (berada di luar daerah toleransi).

Rozi [19] menyebutkan, bahwa jastifikasi radikal yang ditujukan pada kelompok ini biasnya, disebabkan karena mereka umumnya bersifat intoleran, baik berupa fundamentalis intoleran, ekstrim intoleran maupun militan intoleran. Ada dua hal yang menyebabkan kelompok Islam Radikal ini mendapat sorotan masyarakat luas; Pertama, adanya intoleransi mereka terhadap pandangan-pandangan, sikap, serta perilaku yang berlainan. Sikap intoleransi ini bisa saja dalam bentuk protes, demo, tetapi tidak menutup kemungkinan visualisasinya akan berubah menjadi sebuah kekerasan masa. Kedua, adanya kelompok radikal agama yang mempunyai kebiasaan untuk membentuk bagian-bagian khusus dalam kubu organisasi mereka yang perkembangan lebih lanjut tumbuh menjadi para militer.

\section{Pandangan Islam Moderat (Islam Nusantara)}

Di dalam Islam moderat, khususnya Islam Nusantara terdapat poin-poin penting yang dapat dikaitkan dengan manajemen pendidikan Islam, yaitu: (a) Pemahaman Islam Moderat tepo seliro. Islam moderat memandang pemahaman Islam dari sudut pandang kemaslahatan umat manusia secara meneluruh. Islam masuk ke Indonesia dengan jalan damai, karena para penyebar agama Islam ke wilayah nusantara menggunkan metode yang tepat yaitu metode dakwah persuasif dan bukan konfrontatif. Ajaran Islam pada masa itu sejatinya tidak condong kepada gerakaan Islam radikal dan gerakan Islam liberal, justru mengenalkan Islam moderat dengan toleransi antar umat beragama dakwah dengan gerakan yang sinergis antara budaya yang telah ada sebelumnya.

Sikap yang moderat seperti ini segaja ditumbuhkan di kalangan masyarakat untuk menyebarkan ajaran Islam dengan memformulasi ajaran Islam dengan sinergitas budaya lokal sehingga dalam menyebarkanya tidak mengalami penolakan yang keras bahkan diterima dengan hati yang senang karena tidak meninggalkan tradisi lokal, hanya tradisi tersebut dibingkai dalam syariah Islam. [20] Metode sikap yang arif dan bijak tersebut diambil dari dasar Alquran dan Hadis Nabi saw. Kemudian diajarkan ke dalam ajaran Islam dengan memformulasi menjadi kemasan yang apik dan khas dengan ajaran tepo seliro[21], tepo seliro ini dibangun atas dasar konsep Islam dibangun atas empat prinsip ajaran Islam yaitu: 1) at-tawassuth (moderat), at-tassamuh (toleran), at-tawazun (seimbang) dan al-i'tidal (adil), ajaran tepo seliro yang terbagun dari empat prinsip inilah yang disebut dengan ajaran autentik Islam Indonesia.

Oleh karena itu saat ini perlu membangun kesadaran bersama tentang bagaimana merajut kembali ajaran yang adhi luhur yang mampu mengukir sejarah bahwa Islam hadir tanpa kekerasan dan mampu bersinergi dari berbagai aspek kehidupan, utamanya aspek budaya yang beragam, aspek sosiologi kehidupan yang multikurtur dan aspek teologi yang beragam yang bertujuan untuk membangun peradaban Islam yang lebih bermartabat. Ide dan gagasan yang diajarkan oleh para Wali Sembilan (Wali songgo) di Indonesia dan para ulama salih terdahulu mulai masuk dalam 
pembelajaran yang didesain dalam kurikulum pembelajaran secara teritegrasi dalam membangun kompetensi umat (sumber daya manusia) yang mampu berdaya saing dengan menumbuhkan sikap menjadi manusia yang tepo seliro. Tepo seliro adalah kompetensi sikap yang mampu meletakan sebuah ajaran agama Islam atau mengamalkan ajaran agama Islam sesuai dengan situasi dan kondisi dengan mengutamakan kepentingan kebersamaan dan kemanusiaan dengan prinsip Khairunas anfauhun linnas. (b) Mengembangkan ajaran Islam Moderat dalan lembaga pendidikan. Lembaga pendidikan pada saat ini dipandang masyarakat satu-satunya tempat yang paling strategis untuk mengembangkan potensi dan kompetensi anak bangsa, di dalam pendidikan lah anak dididik untuk menjadi dewasa secara intelektual dan keterampilan dan sikap (moral), yang ironinya apabila anak sudah didik dalam proses pembelajaran dikelas atau lembaga pendidikan, para orang tua sudah yakin dan sepenuhnya menyerahkan dan jarang melakukan kontrol bagaimana prosesnya dan bagaimana penanaman sikapnya, oleh karena itu proses pendidikan memiliki tanggung jawab yang tinggi dan ikut andil yang sangat luas terhadap mutu pendidikan yang diselenggaran, termasuk moralitas mutu lulusan.

Dalam organ pendidikan salah satu sub sistem dalam manajemen pendidikan adalah kurikulum, kurikulum adalah organ penting dalam dunia pendidikan ia berfungsi sebagai otaknya dalam pendidikan. Apabila salah dalam proses transfer ilmu pengetahuan dan transfer pembelajaran agama Islam, maka yang terjadi akan jauh menyimpang dari ajaran Islam itu sendiri, apakah ia akan menjadi manusia yang toleran atau akan menjadi manusia yang radikal. Bentuk pengembangan kurikulum meliputi empat unsur kurikulum, yang terpenting yaitu unsur materi (isi kurikulum), unsur proses yang dilakukan dalam kegiatan pembelajaran, unsur tujuan yaitu menanamkan rasa tolerasi atau tawassuth dalam paham agama dan amalanya dalam kehidupan serta mampu menegakan kebenaran tanpa kekerasan, unsur evaluasi yaitu untuk mengetahui keberhasilan dan penyempurnaan kurikulum tersebut. (c) Pengamalan Islam melalui aksi-aksi dalam pembelajaran yang terintegrasi. Kegiatan dalam pembelajaran di lembaga pendidikan secara umum mampu didiskripsikan kegiatan pembelajaran yang secara bersama-sama laki dan perempuan, dan tidak membedaan suku dan ras dengan menjujung tinggi tolerasi dan demokrasi serta mendorong untuk mempertahankan semangat nasionalisme bernegara dan berbangsa (subanul wathon minal iman) cinta kepada negara sebagian dari iman ungkapan tokoh NU pada tahun 1959 oleh K.H. Shahal Mafud. Dalam konteks kehidupan berbangsa dan bernegara tetap melestarikan budaya yang lama (tradisi) yang masih relevan dan semangat Negara Kesatuan Republik Indonesia (NKRI) harga mati tidak bisa digantikan ideologi lain, ideologi Pancasila sebagai pedomoman hidup bangsa Indonesia merupakan bentuk pemersatu bangsa, Pancasila yang terdiri dari lima sila, berisikan mulai dari ketuhanan, kemanusiaan atau hak asasi manusia, persatuan Indonesia dan keadilan yang berkemakmuran adalah cita-cita kehidupan bangsa yang luhur, pernyataan dalam sila pertama sampai sila ke lima menurut penulis tidak ada yang bertentangan dengan Ajaran Islam yang moderat.

Ideologi Pancasila dari yang lain merupakan jati diri bangsa yang berbentuk identitas sebagai ciri kenegaraan bila dibandingan dengan falsafah negara lain yang mengedepankan persamaan derajat dalam kehidupan berbangsa dan bernegara. Dalam pandangan penulis bahwa mengamalkan Pancasila dalam kehidupan sehari-hari merupakan jihad dalam kehidupan bermasyarakat dan berbangsa serta bernegara dalam naungan NKRI, oleh karena itu mengamalkan dalam kehidupan bermasyarakat dan bernegara tidak identik dengan perang. 


\section{Pembiasaan-pembiasaan yang mendekatkan dengan nilai luhur Bangsa Indonesia.}

Proses pembiasaan dalam kehidupan masyarakat yang majemuk agama, budaya dan bahasa seperi Indonesia sekarang ini, sangat diperlukan pembiasaan kehidupan yang toleran, tepo seeliro, menegakan kebenaran tanpa kekerasan, membiasakan jihad di bidang pendidikan menjadikan insan kamil, menjadikan manusia qowiyu amiin, serta memiliki perilaku khoirunas anfauhumlinas.

Melalui konsep kurikulum pembelajaran mengajarkan Islam moderat, implementasinya memuat 4 unsur pokok yaitu tujuan, materi (isi), proses dan penilaian, pada sisi tujuan kurikulum mampu mewujudkan peserta didik yang tawassut, tassamuh dan tawazun, sehingga proses pembelajarannya diintegrasikan dalam materi pembelajaran di sekolah dasar sampai perguruan tinggi. Ciri konsep kurikulum dengan isi materi, 1) Perjuangan masyarakat bersama pemerintah berjung melawan penjajah Belanda, merebut kemerdekaan (Resolusi Jihad), mempertahankan kemerdekaan (memberantas Komunis) dan paham radikal lainya, peristiwa besar di negara Republik ini atas kebersamaan masyarakat bersama pemerintah untuk setia dan patuh pada pemimpin, 4). Salah satu Ormas Islam di Indonesia yaitu Nahdlatul Ulama telah menerima dengan bulat tentang azas tunggal Pancasila sebagai azas berpolitik dan bernegara. Dalam pelaksaan pembelajaran diintegrasikan antara isi kurikulum dengan proses pelaksanaan ibadah (PPI), dalam praktek pengamalan ibadah selalu mengedepankan sikap pelaksaaan yang moderat, toleran dan menghargai pendapat orang lain, bentuk peribadahan yang membingkai budaya nasional menjadi budaya Islami (mengislamkan budaya) yang sudah lama dilakukan oleh masyarakat di Indonesia. Ada bentuk peribadahan ubudiyah yang ada di masyarakat. (a) Pada saat lahiran Bayi (keluarga Baru) ada rangkaian ibadah yang mampu mengumpulkan masyarakat dengan bacaan Al Barzanji atau Markaban, (b) Pada peristiwa kematian salah satu keluarga ada kegiatan ibadah yang dilakukan dengan berta'ziah denga membaca surat Yasin dan baacaan tahlil (yasinan dan tahlilan), (c) Pada mendapat nikmat yang sifatnya duniawi maka ada kegiatan peribadahan tasyakuran (genduren), dalam kegiatan ibadah inilah terjadi implementasi pendidikan multikultur yang kuat antara satu suku dengan yang lain tidak pernah berbicara latar belakang ras, kebersamaan antara mereka sehingga telah terjadi pembawuran komunitas. Dalam konteks pratik ibadah semacam hal tersebut akan mampu mentransformasi paham Islam yang moderat anti radikalis, sependapat dengan James Bank 1993 bahwa pendidikan multikultur dapat dilakukan dengan tindakan yang pertama untuk menanamkan mutikultur melalui transformasi pemahaman (knowing), Tomas Likona memaknai transfomabilitas itu dengan kata knowing dan dilihat melaui instuisi, dan aksi, maka jika pemahaman tranformasi keilmuan Islam moderat dapat dilakukan pada Praktek Pengalaman Ibadah, dalam ibadah warga pembelajaran melalui proses pendidikan di sekolah atau lembaga pendidikan ulama selalu memelihara budaya yang ada dan relevan dengan sariat agama Islam. Ada lima tahapan dalam melaksanakan multikultur dalam kehidupan bermasyarakat lebih jelasnya lihat gambar sebagai berikut: 


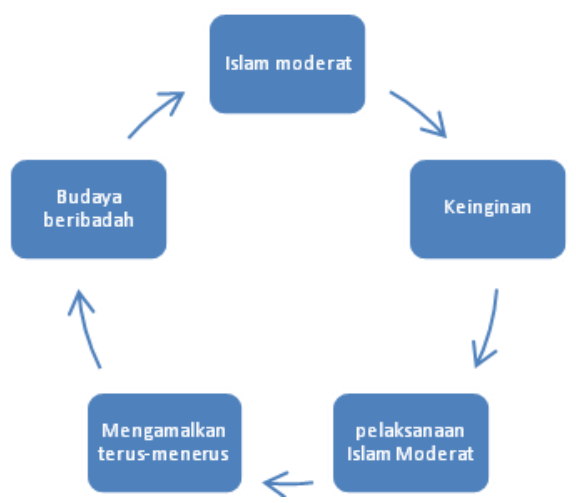

Gambar 1. Langkah-langkah mengamalkan Islam moderat

Berdasarkan pemahaman penulis bahwa pelaksanaan Islam moderat dalam masyarakat, perlu adanya sebuah rancangan yang mampu menerapkan dalam proses kehidupan. Bebarapa tokoh sosial menyatakan ada lima langkah dalam membentuk karakter, yang pertama pemahaman, niat (intuity), perbuatan (action), pembiasaan (habbit) dan yang terakhir adalah karakter, berdasar pengetian ini penulis merujuk hal tersebut, bahwa untu membangun karakter pengamalan Islam moderat dilaksanakan sesuai pada gambar 1. Untuk mampu mengamalkan dalam proses kehidupan bermasyarakat tentang Islam Moderat maka melalui langkah pemahaman terlebih dahulu, dalam memahami tersebut bisa melalui lembaga pendidikan atau pembelajaran, adanya keinginan secara bersama bahwa inilah Islam yang rahmatan lil alamin, bersama-sama untuk dilaksanakan dan mengamalkan dimana saja dan kapan saja dalam rangka menjaga dan melestarikan budaya luhur dan memiliki nilai kemanusiaan yang tinggi.

\section{Mengembangkan Budaya Luhur Bangsa Indonesia}

Diketahui bahwa Indonesia adalah negara kepulauan terbesar di seluruh dunia dengan ciri khas suatu negara yang ramah tamah, menghormati budaya orang lain, mampu hidup berdampingan dengan multi agama dan multi etnis dari sejak pra sejarah hingga masa globalisasi era digitalisasi industi melinial 4.0, ini menunjukan kekokohan bangsa Indonesia untuk mampu secara bersamasama melestarikan budaya nenek moyang yang sangat arif dan luhur.

Indonesia juga diketahui oleh dunia bahwa negara Indonesia adalah negara yang rakyatnya mengaut ajaran Islam yang taat terbesar di seluruh santereo jagat raya ini, hal ini sangat penting untuk diketahui bersama sebab apa, kekuatan yang mampu mempersatukan rakyat Indonesia ini karena masyarakat banyak yang menganut agama Islam yang moderat, yaitu agama Islam yang mengedepankan perdamaian umat yang ada di dunia menuju kesejahteraan bersama.

Perilaku atau perbuatan yang dianjurkan agama Islam yang disebut akhlakul karimah, perilaku ini telah dicontohkan oleh manusia teladan uswatun hasannah, Nabi Muhmmad SAW. Perilaku tersebut antara lain: jujur, adil, amanah, menyampaikan kebenaran tanpa kekerasan, rendah diri. Perkataan Rasullullah dalam hadis yang artinya: Saya (Nabi) diutus di muka bumi ini hanyalah untuk menyempurnakan budi pekerti (akhlah mulia). Budi pekerti atau akhlak mulia merupakan tolak ukur dari arti dan makna secara hakiki proses kehidupan kehidupan manusia di dunia, secara singkat bahwa manusia baik atau tidak dalam proses hidup di dunia lihatlah akhlaknya, baik akhlak dengan Tuhan Yang Maha Esa secara ibadah (hablu minallah), akhlak dengan manusia (hamblun min an-nas). Untuk mampu melihat prilaku manusia dilihat dari empat dimensi dapat digambarkan dalam bentuk diagram sebagai berikut. 


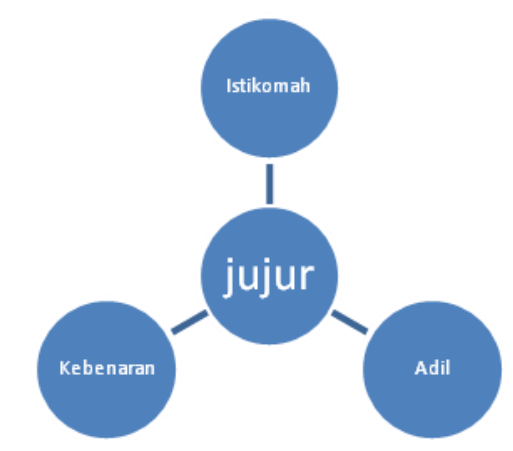

Gambar: 2. Empat dimensi karakter menurut konsep Islam.

Dalam konteks membangun karakter muslim di Indonesia, yang paling utama adalah jujur, perbuatan manusia karakter jujur secara simultan didukung oleh perilaku adil, benar, dan istikomah dalam setiap perbuatan. Mari dikaji bersama tentang kondisi di Negara Kesatuan Republik Indonesia, peristiwa yang memperihatinkan sejak zaman orde baru sampai sekarang zaman reformasi bahkan zama milenial industri 4.0, kondisi bangsa Indonesia adalah bangsa yang korup dan akhir-akhir ini malah menjadi bangsa yang radikal, yang sangat memilukan bahwa Pegawai Negeri Sipil (PNS), hasil BIN sebesar 19,7\% menyatakan Pancasila sudah tidak relevan lagi sebagai dasar negara Republik Indonesia.

Dalam kenyataan fakta seperti ini, ada apakah yang salah dalam mengelola negara ini. Salah satu alternatif jawaban yang mendekati kebenaran menurut analisa penulis adalah, dengan melaksanakan perbuatan atau perilaku yang terpuji dengan cara menjalankan empat dimensi perilaku kehidupan berbangsa dan bernegara.

\section{Kesimpulan}

Lembaga memiliki tanggung jawab yang tinggi untuk menumbuhkan dan menanamkan tentang ragam budaya, ragam agama dan ke-Indosnesia-an, hal tersebut merupakan rekayasa atau ide-ide pengembangan dalam pembelajaran sejak usia sekolah dasar sampai perguruan tinggi, sehingga mampu memberikan dasar-dasar nilai kebangsaan (nasionalisme), toleransi dan tidak berfikir dan bertidak radikal. Penelitian ini adalah peneitian lapangan dengan pendekatan diskriptif kualitatatif dengan alat pengumpul data observasi, wawancara dari beberapa informan kunci dan dianalisa dengan pemikiran induktif. Pengembangan pendidikan multikultur dalam menumbuhkan semangat nasionalisme, dan menderadikalisai paham radikal, dilakukan melalui yaitu:1. Mengintegrasikan Islam moderat dengan penanaman sikap tawassuth, tassamuh, dan tawazun. 2. Mengenalkan lingkunagn sekitar sebagai kemajemukan (contectual learning), 3. Menanamkan sikap keebenaran anti kekerasan rahmatan lil alamin. Ketiga hal tersebut sebagai rekayasa penerapan pengembangan materi, terintegrasi secara menyeluruh dalam proses pembelajaran dalam kelas maupun di luar kelas. Simpulan, Pendidikan dilaksanakan secara terprogram dengan cara: 1. Mentranformasi ilmu melalaui pemahaman Islam moderat, 2. Mengadopsi budaya yang baik (khasanah), 3. Melakukan aksi nyata di lingkungan pendidikan dengan sikap tawassuth, tassamuh dan tawazun, amar ma'ruf nahimunkar anti kekerasan 4. Dilakukan dalam bentuk perilaku dan mengembangkan kosep toleran tepo seliro pada semua lini proses pembelajaran dan 5. Karakter nasionalisme dalam kehidupan (Khoirunas Anfauhum Linnas ). Dampak yang timbul secara berlahan mengenal Islam moderat, menumbuh kembangan nasionalsme kebangsaan memupuk rasa cinta tanah air sebaagai wujud pelestarian Islam rahmatan lil alamin dalam memperkokoh persatuan bangsa Indonesia. 


\section{Daftar Pustaka}

[1] "Dari Mako Brimob sampai Polrestabes Surabaya: Satu minggu penuh teror," 14-May-2018.

[2] S. Subandi, "Menderadikalisasi Paham Radikal Melalui Pendidikan Multikultur dan Karakter Lokal di Lampung | FIKRI : Jurnal Kajian Agama, Sosial dan Budaya.” [Online]. Available: https://journal.iaimnumetrolampung.ac.id/index.php/jf/article/view/175. [Accessed: 05-Dec-2018].

[3] "BIN Ungkap, 39 Persen Mahasiswa Tertarik pada Paham Radikal - Tribunnews.com." [Online]. Available: http://www.tribunnews.com/nasional/2018/11/21/bin-ungkap-39persen-mahasiswa-tertarik-pada-paham-radikal. [Accessed: 05-Dec-2018].

[4] E. J. Hobsbawm and T. O. Ranger, Eds., The invention of tradition, 19th pr. Cambridge: Cambridge Univ. Pr, 2010.

[5] E. Handoyo and Tijan, Model Pendidikan Karakter Berbasis Konservasi: Pengalaman Universitas Negeri Semarang. Semarang: Widya Karya Press, 2010.

[6] M. S. Hanafy, "PENDIDIKAN MULTIKULTURAL DAN DINAMIKA RUANG KEBANGSAAN," vol. 3, no. 1, 2015.

[7] Sugiyono;, Memahami Penelitian Kualitatif. Alfabeta, 2008.

[8] L. Elton, University Teaching: A Professional Modelfor Quality. Buckingham: Openuniversity Press, 1995.

[9] L. J. Moleong, Metodologi Penelitian Kualitatif. Bandung: Remaja Rosdakarya, 2006.

[10] E. Kusnadi, Metodologi Penelitian. Metro: Ramayana Pers dan STAIN Metro, 2008.

[11] N. Muhadjir, Metodologi Penelitian Kualitatif. Yogyakarta: Rake Sarasin, 1998.

[12] M. B. Miles and Huberman, Qualitative Data Analysis a Sourcebook of New Methods. London: SAGE Publication Ltd, 1995.

[13] S. Kartodirdjo, Pemberontakan Petani Banten: Kondisi, Jalan Peristiwa, dan Kelanjutannya, Sebuah studi Kasus Mengenai Gerakan Sosial di Indonesia. Jakarta: Pustaka Jaya, 1995.

[14] Z. Fananie, Radikalisme Keagamaan dan Perubahan Sosial. Surakarta: Muhammadiyah University Press, 2002.

[15] M. I. Rahmat, Arus Baru Islam Radikal: Transmisi Revivalisme Islam Timur Tengah ke Indonesia. Erlangga, 2005.

[16] M. Sulhan, H. Hasbiyallah, and D. N. Haq, "Prophetic Bases of Islamic Moderation of State Islamic Higher Education (PTKIN)," vol. 261, p. 6.

[17] W. M. Watt, "Fundamentalisme Islam dan Modernitas," Jakarta: PT. Rajagrafido Persada, 1997.

[18] D. Adamson and R. Bromiley, "Community empowerment in practice," Lessons from Communities First, 2008.

[19] A. B. Rozi, "RADIKALISME DAN PENYIMPANGAN IDEOLOGI GERAKAN SALAFI," EMPIRISMA, vol. 26, no. 1, Jul. 2017.

[20] A. Azra, "Jaringan Global dan Lokal Islam Nusantara," Bandung: Mizan, 2002.

[21] B. Fauzy, A. Sudikno, and P. Salura, "The Resilience of Javanese Meaning in the Architectural Acculturation of Javanese with Chinese Ethnic Houses in the Kampong of Sumber Girang and Babagan in Lasem," J. Basic. Appl. Sci. Res, vol. 2, no. 8, pp. 7741-46, 2012. 